\title{
Microstructure evolution in CuZrAl alloys during ball-milling
}

\author{
K. Tomolya ${ }^{1 *}$, D. Janovszky ${ }^{1}$, M. Benke ${ }^{2}$, A. Sycheva ${ }^{1}$, M. Sveda ${ }^{1}$, T. Ferenczi ${ }^{2}$, P. Pekker ${ }^{1}$, I \\ Cora $^{1}$, A. Roósz ${ }^{1}$ \\ ${ }^{1}$ MTA-ME Materials Science Research Group, Miskolc-Egyetemvaros H-3515, Hungary \\ ${ }^{2}$ University of Miskolc, $H$-3515 Miskolc-Egyetemvaros, Hungary \\ *corresponding author: femkinga@uni-miskolc.hu
}

\begin{abstract}
The microstructure evolution during mechanical milling was studied in the $\mathrm{CuZrAl}$ system. The compositions lay on the two liquidus surfaces indicating different solidification processes in the three alloys. $\mathrm{Cu}_{(55-\mathrm{x})} \mathrm{Zr}_{(35+\mathrm{x})} \mathrm{Al}_{10}(\mathrm{x}=0 ; 5 ; 10$ at\%) master alloys were produced by arc melting. After identification of the phases, the master alloys were milled for 25 hours and amorphous/crystalline powders were synthesized. The master alloys contained $\mathrm{Al}_{21} \mathrm{Cu}_{28} \mathrm{Zr}_{51}, \mathrm{AlCu}_{2} \mathrm{Zr}, \mathrm{CuZr}$ and traces of $\mathrm{Cu}_{10} \mathrm{Zr}_{7}$ phases in different volume fractions. The optimal milling time was determined to be 15 hours based on the results of X-ray diffractometry (XRD) and differential scanning calorimetry (DSC) examinations. The $5 \mathrm{~h}$ milled powder contained $\mathrm{CuZr}$ and $\mathrm{Al}_{21} \mathrm{Cu}_{28} \mathrm{Zr}_{51}$ phases, which diminished due to further milling resulting in amorphous matrix composite with nanosized $\mathrm{Al}_{21} \mathrm{Cu}_{28} \mathrm{Zr}_{51}$ phase. The thermal stability of the samples was investigated by DSC. The peak temperatures of the first crystallization process of the as-milled powders shifted as function of milling time and polynomial curves were fitted to the measured points.
\end{abstract}

Keywords: $\mathrm{CuZrAl}$ alloys, amorphous/nanocrystalline composite, ball-milling, powders

\section{Introduction}

$\mathrm{Cu}-\mathrm{Zr}$ based bulk metallic glasses (BMGs) attracted high attention because of their relatively low costs [1-3]. Aluminum has been regarded as useful element to improve the plasticity of the CuZr-based BMGs [4]. The addition of minor Al quantities (up to 10 at\%) to the $\mathrm{Cu}-\mathrm{Zr}$ glassy alloys may improve their thermal stability, mechanical properties and glass forming ability (GFA) [5, 6].

Glassy alloys can be produced by casting and by solid state techniques such as mechanical alloying (MA) [7-10, 12] or mechanical milling (MM) [8, 11-13]. Both solid state techniques have now been shown to be capable of synthesizing a variety of equilibrium and nonequilibrium alloy phases starting from blended elemental or prealloyed powders. Additionally, powders can be mechanically activated to cause chemical reactions at near to room temperature, which is normally required to produce pure metals, nanocomposites, and a variety of commercially useful materials. The non-equilibrium phases synthesized include supersaturated solid solutions, metastable crystalline and quasicrystalline phases, nanostructures, and amorphous alloys. The advantage of MM over MA is that only reduction in particle size and transformation in the structure need to be induced mechanically since the powders are already alloyed, so the time required for processing is short. During milling, the effect of transmitted mechanical energy causes the formation of amorphous structure in the initial, crystalline powders. In a planetary ball-mill, both the vials and the support disk rotate around their own axes. Due to the centrifugal force produced by these rotations, the grinding balls impact to each other and to the wall of the vial while some amount of powder is trapped in between them [9]. Coalescence and fragmentation of the particles keep balance, because of the high mechanical stress effects caused by the balls. Repeated mechanical mixing, cold welding and fracturing take place and cause the formation of a fine powder with a changed 
structure. During the process, crystal defects e.g. dislocations, stacking faults and twin faults are introduced [14-15] and enhance disordering in the solid state. This disordering may finally cause solid-state amorphization. The production of BMG composites via powder consolidation has the advantage that the reinforcing particles can be distributed more easily. Accordingly, in this work crystalline $\mathrm{Cu}_{(55-\mathrm{x})} \mathrm{Zr}_{(35+\mathrm{x})} \mathrm{Al}_{10}(\mathrm{x}=0 ; 5 ; 10$ at\%) alloys were ballmilled. We are going to report the microstructure evolution during mechanical milling. Sizes and types of the initial and the residual phases of the powders milled up to for 25 hours were identified and compared to each other.

\section{Experimental procedures}

Master alloy ingots with the compositions of $\mathrm{Cu}_{(55-\mathrm{x})} \mathrm{Zr}_{(35+\mathrm{x})} \mathrm{Al}_{10}(\mathrm{x}=0 ; 5 ; 10$ at $\%)$ were prepared by arc melting the mixtures of $\mathrm{Cu}, \mathrm{Zr}, \mathrm{Al}$ pure metals under purified argon atmosphere. The master alloys were grinded and fractioned to a particle size below $300 \mu \mathrm{m}$ for ball-milling. The mechanical milling was performed in a Pulverisette 5 high-energy ballmill in argon atmosphere using stainless steel vial and balls with a diameter of 5, 7 and $10 \mathrm{~mm}$ [21]. The overall process lasted $25 \mathrm{~h}$. The milling process was interrupted every hour. Each interruption was followed by a period of 2 hours to cool down the vials. The milled powder samples were extracted every 5 hours in order to examine the progress of amorphization reaction.

In order to expose the microstructure, both the master alloys and the powders were embedded in acrylic resin, then polished and etched with $0.5 \%$ hydrofluoric acid for $5 \mathrm{sec}$. The structure of each master alloy ingot and each powder was investigated by a Hitachi S4800 Field Emission Scanning Electron Microscope (SEM) equipped with a Bruker AXS Energydispersive X-ray Spectrometer (EDAX) system, a FEI Technai $\mathrm{G}^{2}$ Transmission Electron Microscope (TEM) and a Philips PW 1830 X-ray diffractometer (XRD) with monochromatized $\mathrm{CuK} \alpha$ radiation of $0.15418 \mathrm{~nm}$ wavelength using an anode voltage of 40 $\mathrm{kV}$ and a current of $305 \mathrm{~mA}$. The amorphous fraction was determined by evaluation of XRD patterns. Using a combination of free software Fityk 0.98 and software developed by us (GerKiDo), different curves can be fitted to selected measuring points. The amorphous fraction can be calculated after measuring the area under the curves described in detail in Ref. 22. The thermal analysis was performed by a Netzsch 204 Differential Scanning Calorimeter (DSC) with a heating rate of $0.67 \mathrm{~K} / \mathrm{s}$.

In order to determine the specific surface area, the nitrogen absorption-desorption performance of the as-milled powders was studied by a Tristar 3000 equipment using the conventional volumetric method of nitrogen adsorption/desorption isotherms at the liquid nitrogen temperature and relative pressure $(\mathrm{P} / \mathrm{Po})$ ranging from 0.01 to 1.0 and calculated by the Langmuir method. The particle sizes were measured by a Horiba LA-950V2 particle size analyzer.

\section{Results and discussion}

\subsection{Analysis of the master alloy ingots}

Fig. 1 presents the liquidus projection of the $\mathrm{Al}-\mathrm{Cu}-\mathrm{Zr}$ system calculated by $\mathrm{H}$. Bo et al. [23] marked with the composition studied in this work. Three compositions in this system were selected in order to investigate the amorphization procedure caused by milling. Two of them are on the same liquidus surface $\left(\tau_{4}: \mathrm{AlCu}_{2} \mathrm{Zr}\right)$ and the third belongs to another $\left(\tau_{3}\right.$ : $\mathrm{Al}_{21} \mathrm{Cu}_{28} \mathrm{Zr}_{51}$ ) surface. 


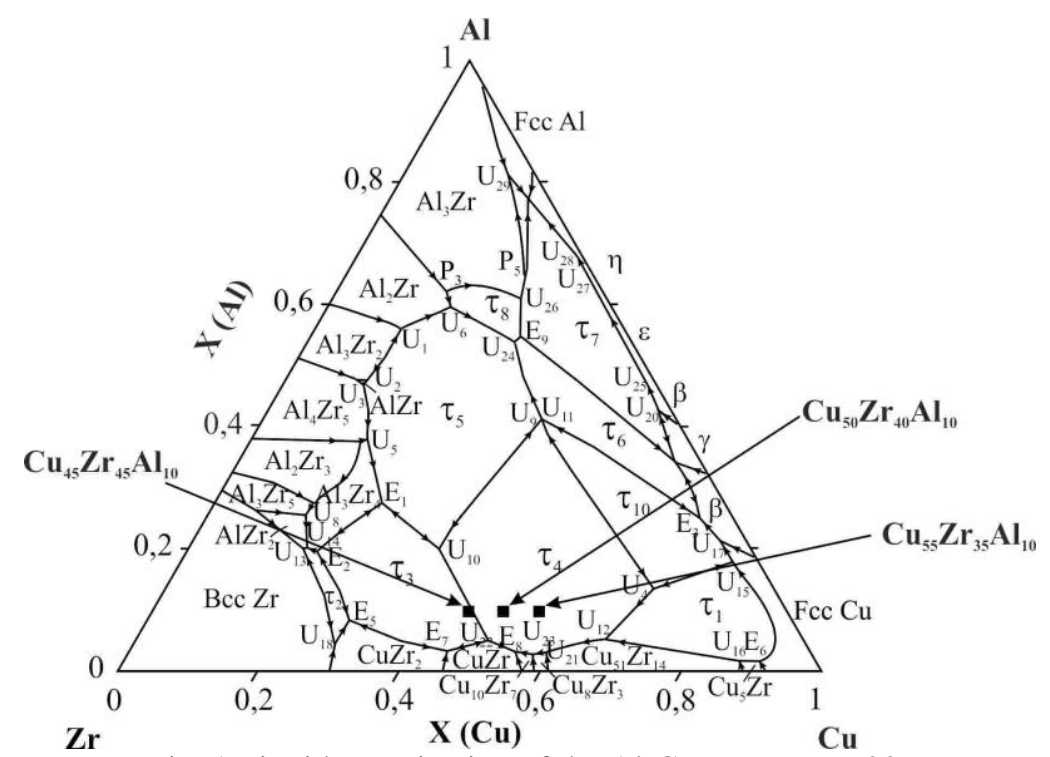

Fig. 1 Liquidus projection of the Al-Cu-Zr system [22]

Before analyzing the structure in the master alloys the expected phases can be determined based on the projection. It is worth mentioning that the cooling rate during production of the master alloy by arc-melting was on the order of $\sim 100 \mathrm{~K} / \mathrm{s}$ and so the solidified structure was far from the equilibrium state. Based on the SEM analysis, results of EDAX and X-ray diffraction patterns, the formed phases of the master alloys have been identified.
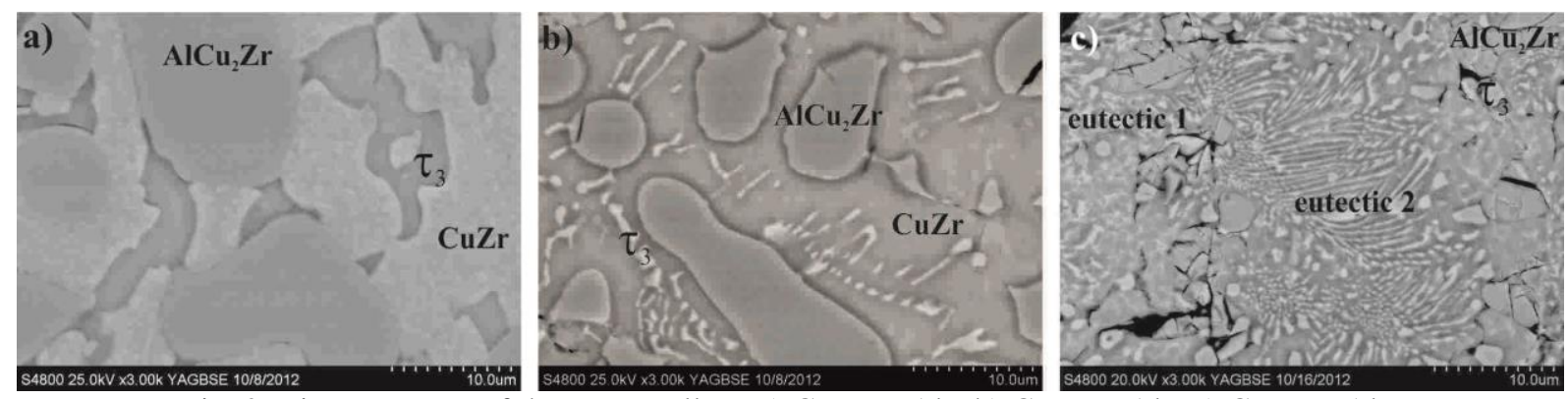

Fig. 2 Microstructure of the master alloys a) $\mathrm{Cu}_{55} \mathrm{Zr}_{35} \mathrm{Al}_{10}$ b) $\mathrm{Cu}_{50} \mathrm{Zr}_{40} \mathrm{Al}_{10}$ c) $\mathrm{Cu}_{45} \mathrm{Zr}_{45} \mathrm{Al}_{10}$

Observing the microstructures of the master alloys in Fig. 2, it can be seen that the same phases formed, being $\mathrm{Al}_{21} \mathrm{Cu}_{28} \mathrm{Zr}_{51}, \mathrm{AlCu}_{2} \mathrm{Zr}$, and $\mathrm{CuZr}$, which was proved by the results of XRD (Fig. 3). Furthermore, some peaks belonging to $\mathrm{Cu}_{10} \mathrm{Zr}_{7}$ were found in the alloys based on the XRD analysis, which overlapped the peaks of $\mathrm{CuZr}$. Selected area electron diffraction (SAED) patterns acquired by TEM confirmed the presence of all the found phases, which is illustrated in Fig. 4. 

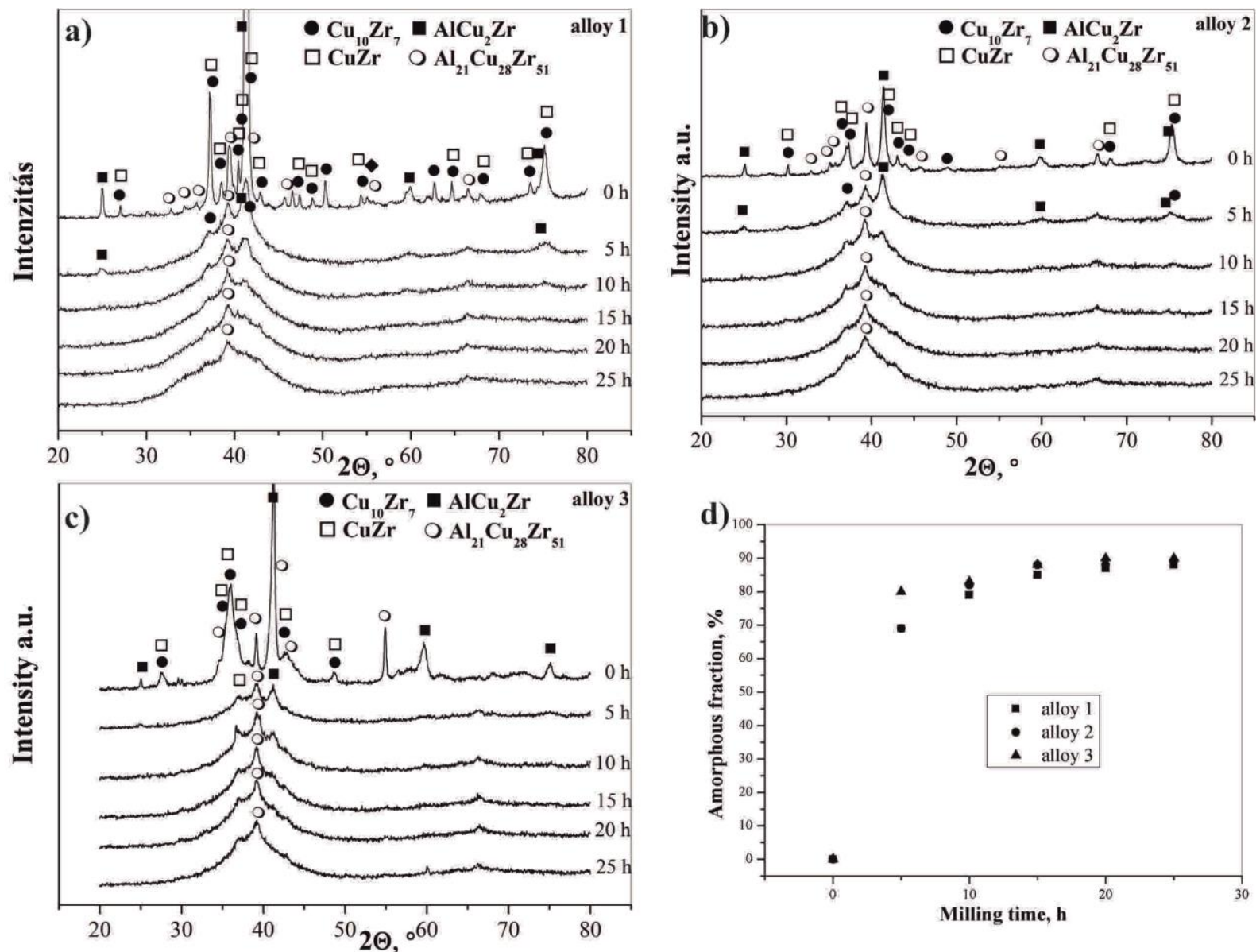

Fig. $3 \mathrm{X}$-ray diffraction patterns of the master alloys and the as-milled powders in case of $\mathrm{Cu}_{55} \mathrm{Zr}_{35} \mathrm{Al}_{10}$ (a), $\mathrm{Cu}_{50} \mathrm{Zr}_{40} \mathrm{Al}_{10}$ (b), $\mathrm{Cu}_{45} \mathrm{Zr}_{45} \mathrm{Al}_{10}$ (c) and amorphous fraction vs. milling time (d)

This figure displays bright-field images of the alloys with the marked phases. CuZr has a lamellar structure, while $\mathrm{Al}_{21} \mathrm{Cu}_{28} \mathrm{Zr}_{51}$ appears as large corns with a size of few micrometres. $\mathrm{Al}_{21} \mathrm{Cu}_{28} \mathrm{Zr}_{51}$ and $\mathrm{AlCu}_{2} \mathrm{Zr}$ have a face-centered cubic cell with $\mathrm{a}_{0}=12.28(2) \AA$ and $\mathrm{a}_{0}=6.28(2)$ $\AA$, respectively. The $\mathrm{Cu}_{10} \mathrm{Zr}_{7}$ phase has an orthorhombic unit cell with parameters of $\mathrm{a}_{0}=$ 9.48(2) $\AA, \mathrm{b}_{0}=9.44(2) \AA, \mathrm{c}_{0}=12.74 \AA$ and $\mathrm{CuZr}$ has a monoclinic unit cell with $\mathrm{a} 0=6.7 \AA, \mathrm{b}_{0}=$ $8.4 \AA, \mathrm{c}_{0}=5.4 \AA, \beta=104^{\circ}$. $\mathrm{Cu}_{55} \mathrm{Zr}_{35} \mathrm{Al}_{10}$ alloy was chosen as initial composition. Modifying the ratio of the $\mathrm{Cu} / \mathrm{Zr}$, i.e. reducing the $\mathrm{Cu}$ amount, the quantity of $\mathrm{AlCu}_{2} \mathrm{Zr}$ did not change significantly, the quantity of $\mathrm{CuZr}$ increased apparently and the $\mathrm{Al}_{21} \mathrm{Cu}_{28} \mathrm{Zr}_{51}$ decreased in the case of $\mathrm{Cu}_{50} \mathrm{Zr}_{40} \mathrm{Al}_{10}$ alloy.
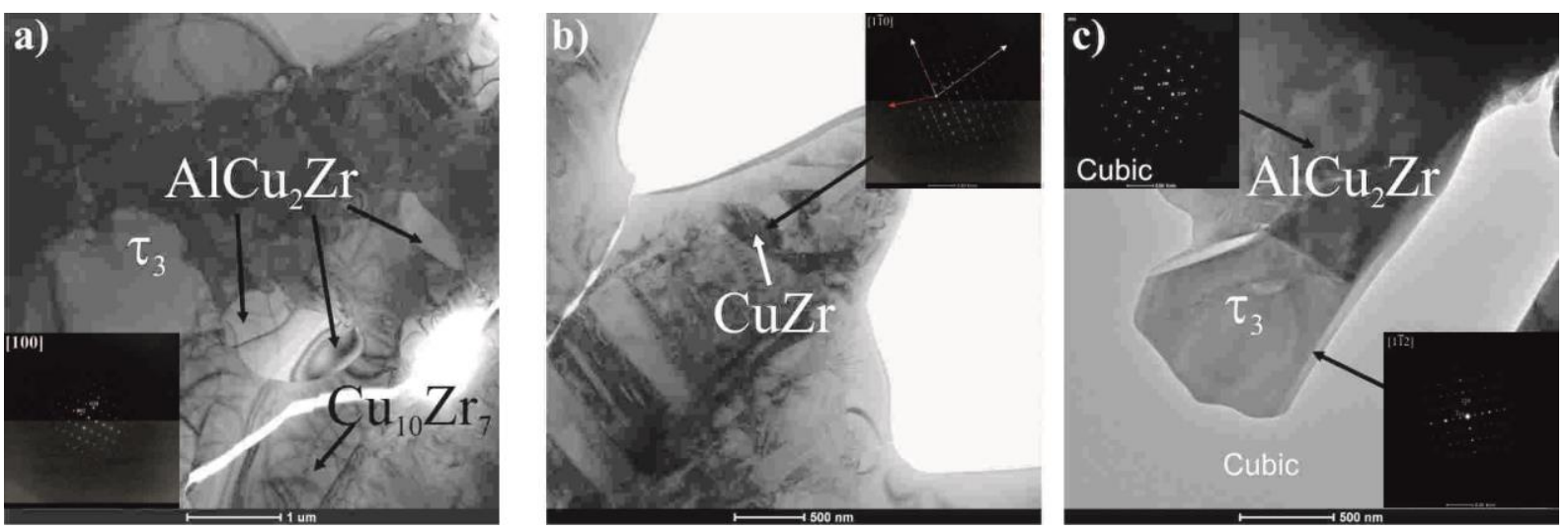

Fig. 4 TEM bright-field images of the master alloys a) $\mathrm{Cu}_{55} \mathrm{Zr}_{35} \mathrm{Al}_{10}$ b) $\mathrm{Cu}_{50} \mathrm{Zr}_{40} \mathrm{Al}_{10}$ c) $\mathrm{Cu}_{45} \mathrm{Zr}_{45} \mathrm{Al}_{10}$ with corresponding electron diffraction pattern 
Traces of $\mathrm{Cu}_{10} \mathrm{Zr}_{7}$ were found by TEM, as well. Moreover, the alloy with a composition of $\mathrm{Cu}_{45} \mathrm{Zr}_{45} \mathrm{Al}_{10}$ alloy had a different structure with the same phases. Two single phases, the $\mathrm{AlCu}_{2} \mathrm{Zr}$ and the $\mathrm{Al}_{21} \mathrm{Cu}_{28} \mathrm{Zr}_{51}$ solidified, which did not form eutectic structure. Additionally, there were two eutectic compounds with phases $\mathrm{Al}_{21} \mathrm{Cu}_{28} \mathrm{Zr}_{51}+\mathrm{CuZr}$ in eutectic 1 and $\mathrm{Al}_{21} \mathrm{Cu}_{28} \mathrm{Zr}_{51}+\mathrm{AlCu}_{2} \mathrm{Zr}$ in eutectic 2 identified, as well, which can be observed in Fig. 2.

\subsection{Analysis of the as-milled powders}

For all the samples studied in this work, 25 hours were selected as maximal milling time. This time was chosen based on the results of our previous research [21], which can be sufficiently long to reach a structure transformation, but short enough to avoid impurities from the milling balls and vial. The progress of amorphization was examined by XRD. Fig. 3 presents the Xray diffraction patterns of the as-milled powders milled for various times. The peak intensities belonging to crystalline phases decreased with increasing milling time and transform gradually to a broad diffuse halo with a maximum at $2 \theta=27-51^{\circ}$. It can be seen that the amorphization progress took place in the first 15 hours, after which no further notable crystalline peak disappeared. During the first 5 hours of milling, $\sim 60$ Volume $\%$ of crystalline structure was amorphized and 89-90 Volume\% of amorphous fraction was obtained after $15 \mathrm{~h}$ of milling (Fig. 3d).

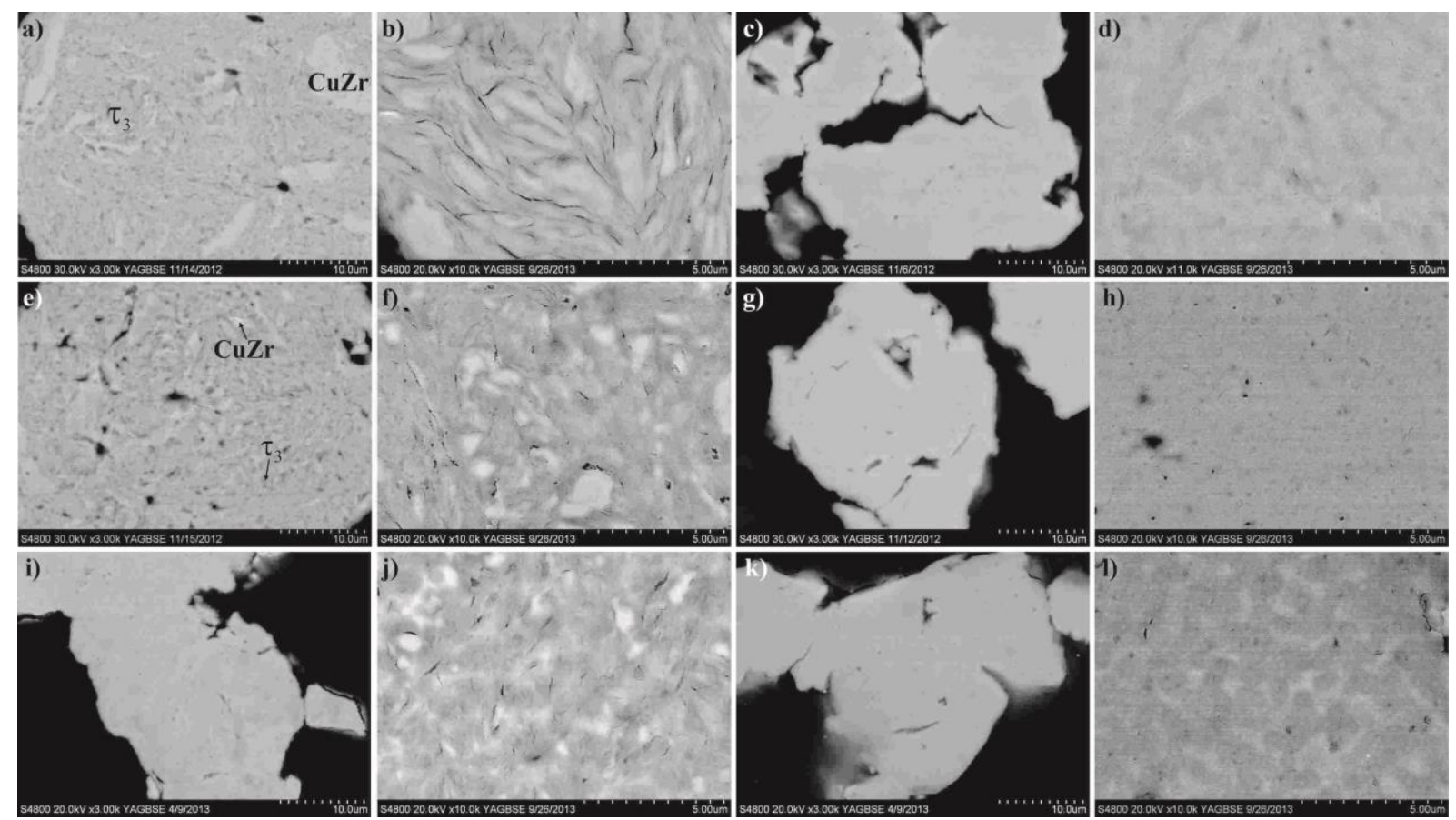

Fig. 5 SEM images of the milled powders a) - b) $\mathrm{Cu}_{55} \mathrm{Zr}_{35} \mathrm{Al}_{10}$ alloy after $5 \mathrm{~h}$ of milling c) - d) $\mathrm{Cu}_{55} \mathrm{Zr}_{35} \mathrm{Al}_{10}$ alloy after $25 \mathrm{~h}$ of milling e) - f) $\mathrm{Cu}_{50} \mathrm{Zr}_{40} \mathrm{Al}_{10}$, alloy after $5 \mathrm{~h}$ of milling g) - h) $\mathrm{Cu}_{50} \mathrm{Zr}_{40} \mathrm{Al}_{10}$ alloy after $25 \mathrm{~h}$ of milling i) $-\mathrm{j}$ ) $\mathrm{Cu}_{45} \mathrm{Zr}_{45} \mathrm{Al}_{10}$ alloy after $5 \mathrm{~h}$ of milling $\mathrm{k}$ ) - l) $\mathrm{Cu}_{45} \mathrm{Zr}_{45} \mathrm{Al}_{10}$ alloy after $5 \mathrm{~h}$ of milling

According to the results of XRD in Fig. 3 and the SEM images in Fig. 5, CuZr and $\mathrm{Al}_{21} \mathrm{Cu}_{28} \mathrm{Zr}_{51}$ phases were identified after 5 hours of milling. The structure of the milled powders shows a mixture of the initial phases at an early stage of milling. In higher resolution images, it can be observed a lot of cracks in the particles owing to the mechanical stress. The original phase boundaries disappeared and the phases were undistinguishable at the end of milling (Fig. 5). The structure of $\mathrm{Cu}_{50} \mathrm{Zr}_{40} \mathrm{Al}_{10}$ alloy looks more uniform compared with the other alloys. The coagulation and fragmentation is achieved during milling, which leads to the formation of cavities and pores in the particles. These can be open or closed pores, which can 
influence the further consolidation. A few peaks belonging to the crystalline structure can be observed in the XRD pattern of powder milled for $25 \mathrm{~h}$, which indicates that no complete amorphization occurred under present milling conditions. Based on the TEM analysis illustrated in Fig. 6, it was revealed that $\mathrm{Al}_{21} \mathrm{Cu}_{28} \mathrm{Zr}_{51}$ exists as residual crystalline phase in the $25 \mathrm{~h}$ milled powders in the case of all three alloys.
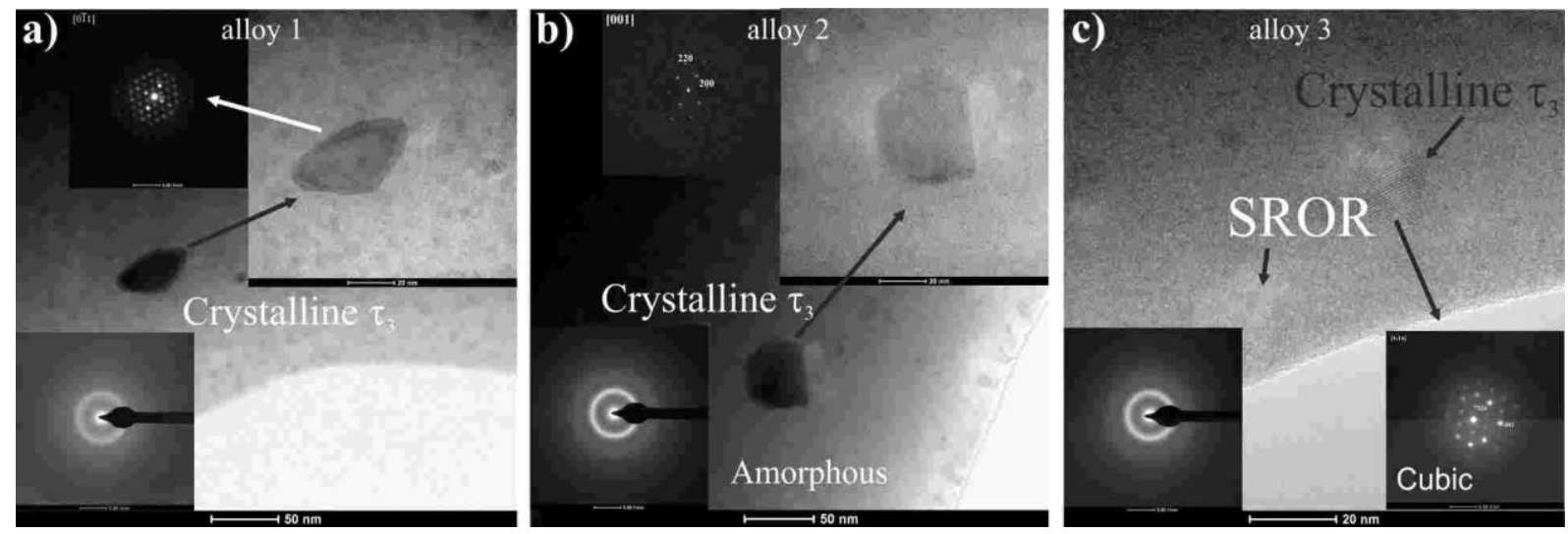

Fig. 6 HRTEM bright-field images of $25 \mathrm{~h}$ milled powders a) $\mathrm{Cu}_{55} \mathrm{Zr}_{35} \mathrm{Al}_{10}$ b) $\mathrm{Cu}_{50} \mathrm{Zr}_{40} \mathrm{Al}_{10}$ c) $\mathrm{Cu}_{45} \mathrm{Zr}_{45} \mathrm{Al}_{10}$ with corresponding electron diffraction patterns $(\mathrm{a}, \mathrm{c})$ and the Fourier-transform $(\mathrm{b})$ of the image

The images show that there are several $\mathrm{Al}_{21} \mathrm{Cu}_{28} \mathrm{Zr}_{51}$ crystalline phases sized from a few nanometres to a few tens of nanometres in the amorphous matrix. The amorphous structure of the matrix was confirmed by SAED patterns. The indices of the diffraction pattern belong to the crystalline phases. In Fig. 6c a cluster of short-range order regions (SROR) are visible, as well. As a result, these powders are actually amorphous-nanocrystalline composites. According to the analysis by EDX attached to the TEM equipment, traces of $\mathrm{Si}, \mathrm{Fe}, \mathrm{Cr}$ impurities are present in the powders after $25 \mathrm{~h}$ milling.

Fig. 7 displays constant-rate heating $(0.67 \mathrm{~K} / \mathrm{s})$ DSC scans of the powders in the temperature range from 500 to $850 \mathrm{~K}$. A typical DSC curve of an amorphous alloy exhibits an endothermic event characteristic of the glass transition $\left(\mathrm{T}_{\mathrm{g}}\right)$ and a distinct undercooled liquid region, followed by one or two exothermic events corresponding to crystallization processes. According to the XRD pattern, the amorphization progressing in the first 15 hours appears to be confirmed, because the peaks become sharper up to 15 hours of milling and after that there is no significant change in all cases. Peak temperatures of the as-milled powders are summarized in Fig. 7d and polynomial curves are fitted to the measured points. According to this function, during the first 15 hours of milling the peak temperatures shifted towards higher values and after that towards lower values. 

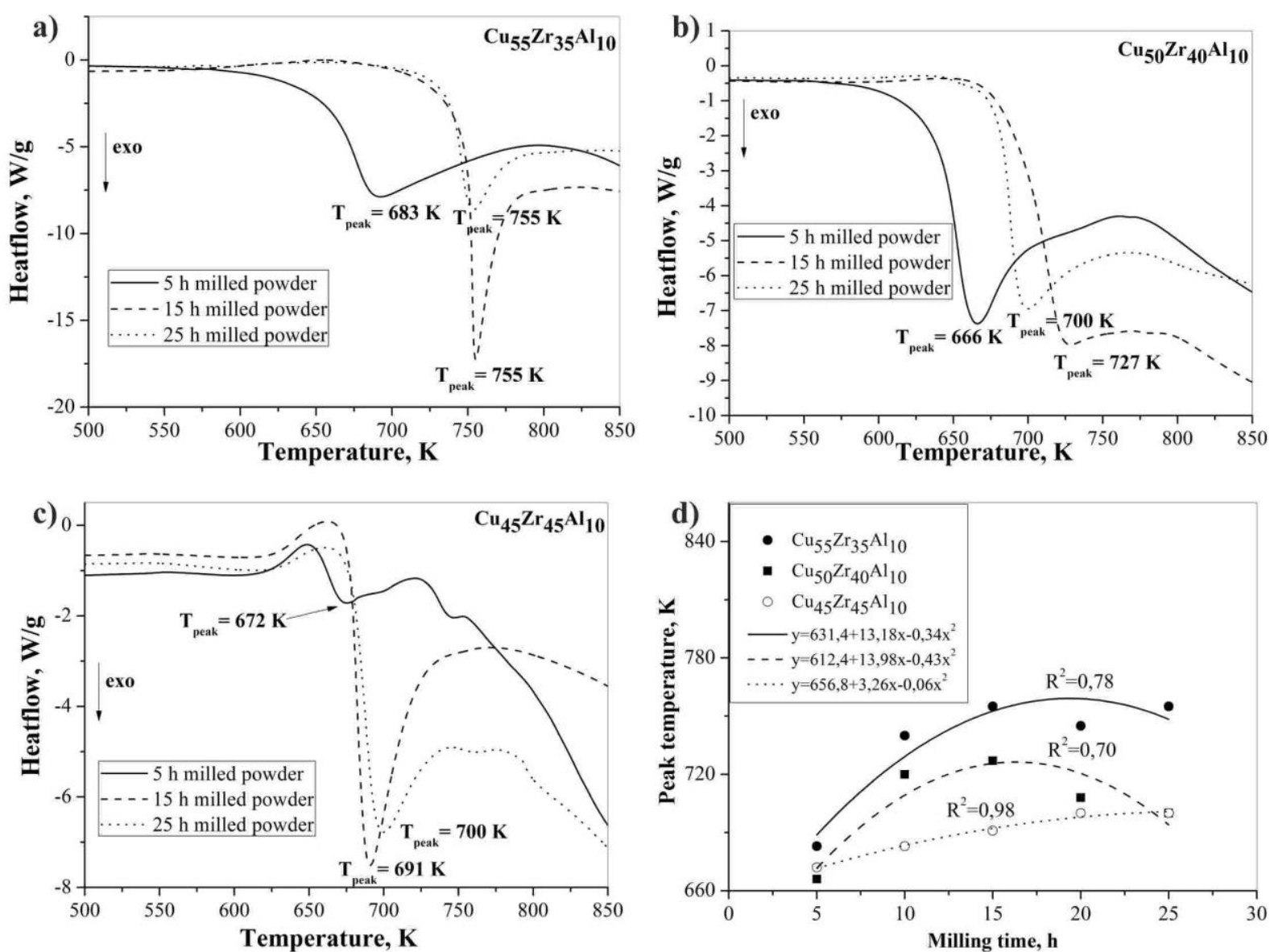

Fig. 7 DSC traces of as-milled powders a) $\mathrm{Cu}_{55} \mathrm{Zr}_{35} \mathrm{Al}_{10}$ b) $\mathrm{Cu}_{50} \mathrm{Zr}_{40} \mathrm{Al}_{10}$ c) $\mathrm{Cu}_{45} \mathrm{Zr}_{45} \mathrm{Al}_{10}$ d) Milling time vs. peak temperatures

Specific surface area and pore size distribution are important properties of powders. A typical isotherm for the as-milled powders is shown in Fig. 8a. A relatively slim hysteresis effect between the absorption and desorption curves indicates the presence of a small number of mesopores (2-50 nanometers) on the surface. Furthermore, it means that the surface of the particles is inactive and does not adsorb nitrogen molecules. 

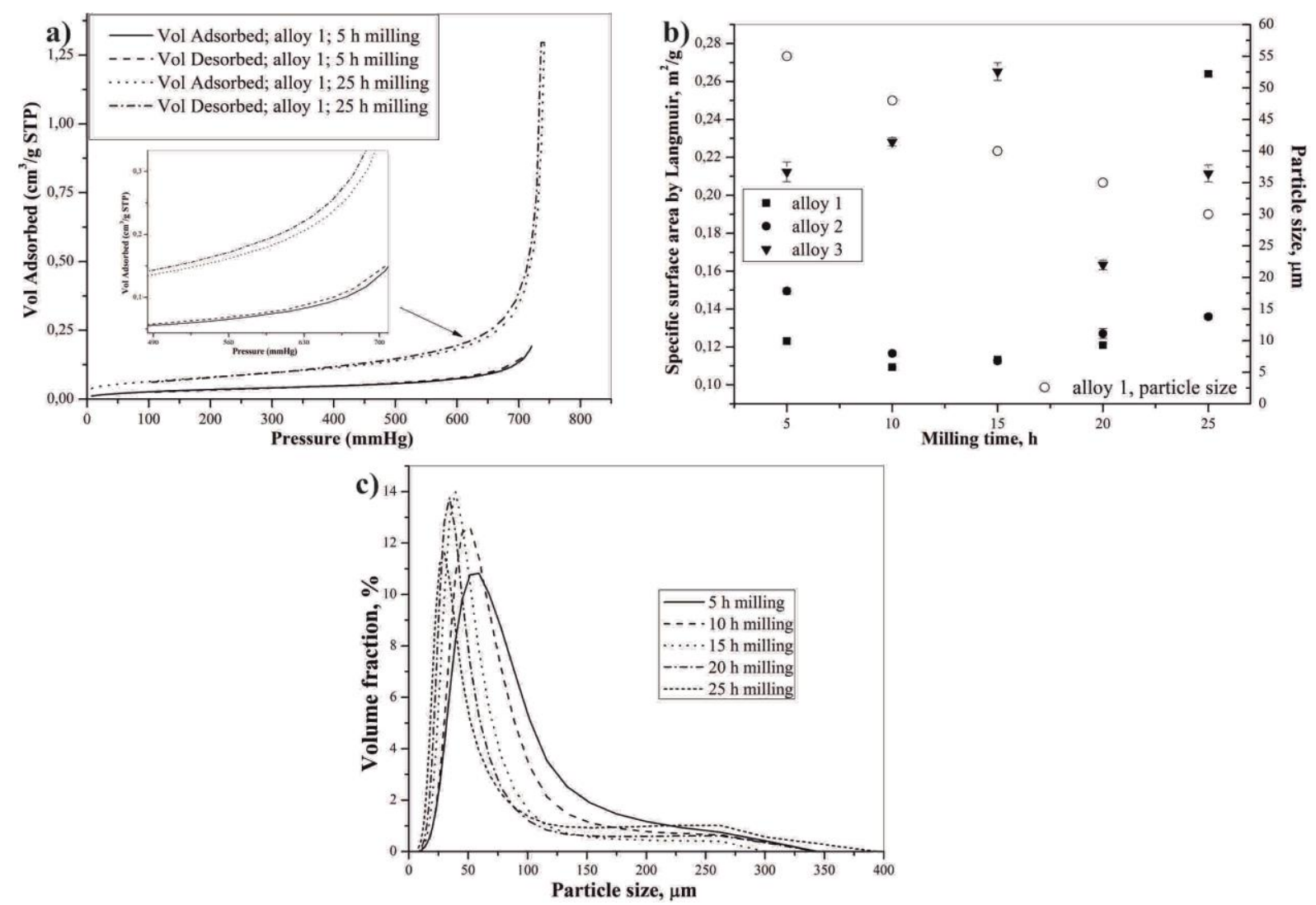

Fig. 8 Specific properties of as-milled powders a) Hydrogen adsorption and desorption b) Specific surface area c) Particle size distribution

Fig. 8b shows the specific surface area calculated by the Langmuir method as function of the milling time. It can be established that the specific surface area has changed slightly during milling; it is nearly constant due to the constant interplay between fracturing and welding. The particle size of the $\mathrm{Cu}_{55} \mathrm{Zr}_{35} \mathrm{Al}_{10}$ alloy decreases monotonically owing to domination of the fracturing over the cold welding during milling. Observing the unimodal particle size distribution of this alloy (Fig. 8c), not only the particles size decreases with milling time but the full width at half maximum of distribution diminishes as well. It indicates that the grain size has become uniform in a narrow range of few tens of microns $(30 \mu \mathrm{m})$ at the end of milling.

Fig. 9 shows the surface of these powders after 20 and $25 \mathrm{~h}$ of milling, which demonstrates pores and surface roughness of the particles. Large particles formed by coagulation of small particles with each other. 

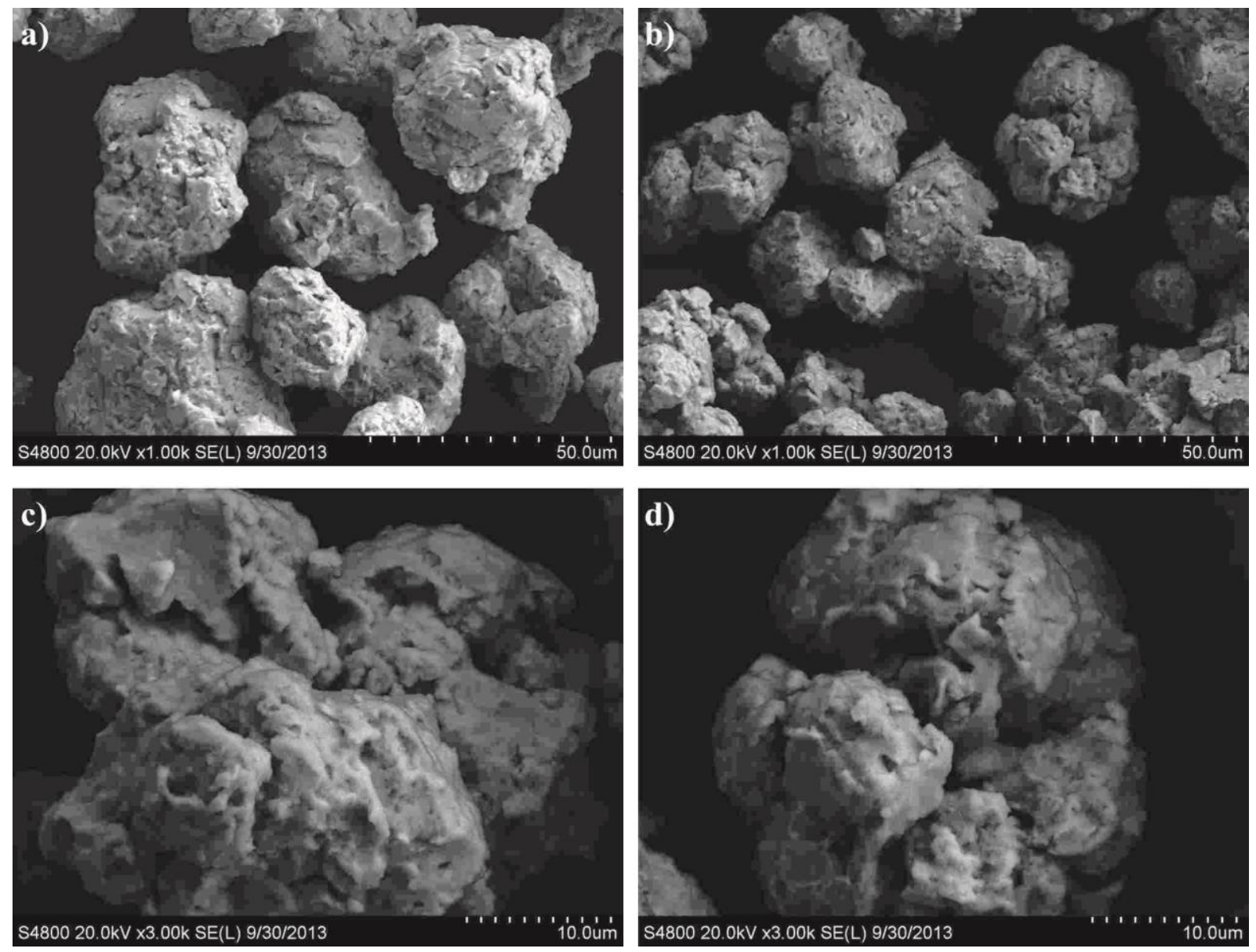

Fig. 9 SEM images of the surface of the $\mathrm{Cu}_{55} \mathrm{Zr}_{35} \mathrm{Al}_{10}$ alloy powders after $20 \mathrm{~h}$ (a, c) and $25 \mathrm{~h}(\mathrm{~b}$, d) of milling

\section{Summary and conclusions}

Amorphous-nanocrystalline composite powders were produced by ball-milling using master alloys with a composition of $\mathrm{Cu}_{(55-\mathrm{x})} \mathrm{Zr}_{(35+\mathrm{x})} \mathrm{Al}_{10}\left(\mathrm{x}=0 ; 5 ; 10\right.$ at\%). There were $\mathrm{Al}_{21} \mathrm{Cu}_{28} \mathrm{Zr}_{51}$ $\left(\tau_{3}\right), \quad \mathrm{AlCu}_{2} \mathrm{Zr}\left(\tau_{4}\right), \mathrm{CuZr}$ and $\mathrm{Cu}_{10} \mathrm{Zr}_{7}$ phases identified in the master alloys. The microstructures of $\mathrm{Cu}_{55} \mathrm{Zr}_{35} \mathrm{Al}_{10}$ and $\mathrm{Cu}_{50} \mathrm{Zr}_{40} \mathrm{Al}_{10}$ alloys are similar; however, the amount of $\mathrm{Al}_{21} \mathrm{Cu}_{28} \mathrm{Zr}_{51}$ decreases and the amount of $\mathrm{CuZr}$ increases with decrease in the $\mathrm{Cu}$ amount. The alloy with a composition of $\mathrm{Cu}_{45} \mathrm{Zr}_{45} \mathrm{Al}_{10}$ had a different structure with the same phases. Two single phases $\left(\mathrm{AlCu}_{2} \mathrm{Zr}\right.$ and $\left.\mathrm{Al}_{21} \mathrm{Cu}_{28} \mathrm{Zr}_{51}\right)$ and two eutectics $\left(\mathrm{Al}_{21} \mathrm{Cu}_{28} \mathrm{Zr}_{51}+\mathrm{CuZr}\right.$ in eutectic 1 and $\mathrm{Al}_{21} \mathrm{Cu}_{28} \mathrm{Zr}_{51}+\mathrm{AlCu}_{2} \mathrm{Zr}$ in eutectic 2) solidified.

In the early milling stage, after $5 \mathrm{~h}$ of milling, the $\mathrm{AlCu}_{2} \mathrm{Zr}$ disappears while 60 Volume $\%$ of the structure amorphizes. The amorphization progressed in the first 15 hours reaching amorphous fraction of 90 Volume\%, after which no significant increase in the volume fraction of amorphous phase was found. At the end of the milling process, after $25 \mathrm{~h}$ of milling only $\mathrm{Al}_{21} \mathrm{Cu}_{28} \mathrm{Zr}_{51}$ phase sized from a few nanometers to a few tens of nanometers remains in the amorphous matrix, resulting in an amorphous matrix nanocrystal in-situ reinforced composites. After $25 \mathrm{~h}$ of milling, the structure of $\mathrm{Cu}_{50} \mathrm{Zr}_{40} \mathrm{Al}_{10}$ alloy looks more uniform compared with the other alloys. This is quite understandable, because the $\mathrm{Al}_{21} \mathrm{Cu}_{28} \mathrm{Zr}_{51}$ phase has the finest structure and distribution in the master alloy.

The specific surface area of the particles during milling changes by increase of roughness and appearance of open pores. The particle size decreases linearly with the milling time.

Based on the results, the $15 \mathrm{~h}$ milling was chosen as optimal milling time and a composition of $\mathrm{Cu}_{50} \mathrm{Zr}_{40} \mathrm{Al}_{10}$ alloy has a more homogeneous structure at the end of milling. 


\section{Acknowledgements}

This work has been carried out as part of the TÁMOP 4.2.4.A/2-11-1-2012-0001 project within the framework of the New Hungarian Development Plan. The realization of this project is supported by the European Union, co-financed by the European Social Fund.

\section{References}

[1] S. Pauly, J. Das, N. Mattern, D.H. Kim, J. Eckert, Intermetallics 17 (2009) 453-462

[2] D.V. Louzguine-Luzgin, G.Q. Xie, S. Gonzales, et al., J. Non-Cryst. Solids 358 (2012) 145-149

[3] L. Zhang, Z. Chen, Q. Zheng, D. Chen, Physica B 411 (2013) 149-153

[4] Y. Wu, H. Wang, H.H. Wu, Z.Y. Zhang, et al., Acta Mater. 59 (2011) 2928-2936

[5] T.L. Cheung, C.H. Shek, J. Alloys Compd. 434-435 (2007) 71-74

[6] K. S. Lee, Y. M. Jo, Y.-S. Lee, J. Non-Cryst. Solids 376 (2013) 145-151

[7] J. Dutkiewicz, L. Jaworska, W. Maziarz, T. Czeppe, et al., J. Alloys Compd. 434-435 (2007) 333-335

[8] H. Kishimura, H. Matsumoto, J. Alloys Compd. 509 (2011) 4386-4389

[9] J. Bhatt, B.S. Murty, J. Alloys Compd. 459 (2008) 135-141

[10] D. Oleszak, T. Kulik, Mater. Sci. Forum 636-637 (2010) 917-921

[11] M.E. Siegrist, M. Siegfried, J.F. Löffler, Mater. Sci. Eng. A 418 (2006) 236-240

[12] C. Suryanarayana, Prog. Mat. Sci. 46 (2001) 1-184

[13] Y.H. Zhao, J. Non-Cryst. Solids 352 (2006) 5578-5585

[14] M. Seidel, J. Eckert, H.-D. Bauer, L. Schultz, Mat. Sci. Forum 225-227 (1996) 119-124

[15] Z. Bian, G.L. Chen, G. He, X.D. Hui, Mater. Sci. Eng. A 316 (2001) 135-144

[21] K. Tomolya, D. Janovszky, T. Janvari, A. Sycheva, et al. J. Alloys Compd. 536 (2012) S154-S158

[22] G. Körösy, K. Tomolya, D. Janovszky, J. Sólyom, Mater. Sci. Forum 729 (2013) 419-423

[23] H. Bo, J. Wang, S. Jin, H.Y. Qi, X.L. Yuan, L.B. Liu, Z.P. Jin, Intermetallics 18 (2010) 2322-2327 